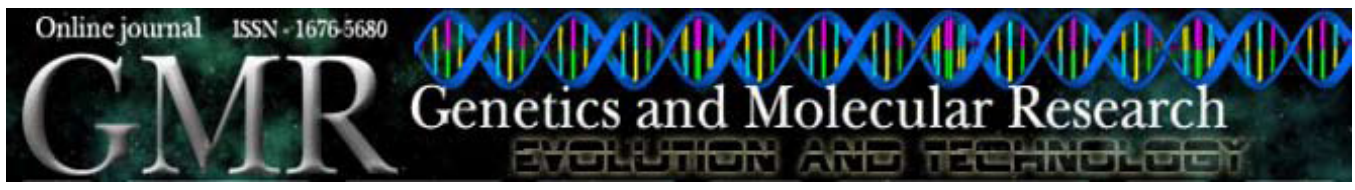

\title{
Characterization of an endophytic bacterial community associated with Eucalyptus spp
}

\author{
R.E.L. Procópio ${ }^{1}$, W.L. Araújo ${ }^{1,3}$, W. Maccheroni Jr. ${ }^{2}$ and J.L. Azevedo ${ }^{1,3}$ \\ 'Departamento de Genética, Escola Superior de Agricultura "Luiz de Queiroz", \\ Universidade de São Paulo, Piracicaba, SP, Brasil \\ ${ }^{2}$ Canavialis, Campinas, SP, Brasil \\ ${ }^{3}$ Núcleo Integrado de Biotecnologia, Universidade de Mogi das Cruzes, \\ Mogi das Cruzes, SP, Brasil \\ Corresponding author: R.E.L. Procópio \\ E-mail: procopio@usp.br
}

Genet. Mol. Res. 8 (4): 1408-1422 (2009)

Received September 14, 2009

Accepted September 17, 2009

Published November 24, 2009

\begin{abstract}
Endophytic bacteria were isolated from stems of $E u$ calyptus spp (Eucalyptus citriodora, E. grandis, E. urophylla, E. camaldulensis, E. torelliana, E. pellita, and a hybrid of E. grandis and E. urophylla) cultivated at two sites; they were characterized by RAPD and amplified rDNA restriction analysis (ARDRA). Endophytic bacteria were more frequently isolated from $E$. grandis and E. pellita. The 76 isolates were identified by $16 \mathrm{~S}$ rDNA sequencing as Erwinia/Pantoea (45\%), Agrobacterium sp (21\%), Curtobacterium sp (9\%), Brevibacillus sp (8\%), Pseudomonas sp (8\%), Acinetobacter sp (4\%), Burkholderia cepacia (2.6\%), and Lactococcus lactis $(2.6 \%)$. Genetic characterization of these endophytic bacteria isolates showed at least eight ARDRA haplotypes. The genetic diversity of 32 Erwinia/Pantoea and 16 Agrobacterium sp isolates was assessed with the RAPD technique. There was a high level of genetic polymorphism among all the isolates and there was positive correla-
\end{abstract}


tion between the clusters and the geographic origin of the strains. These endophytic bacteria were further analyzed for in vitro interaction with endophytic fungi from Eucalyptus spp. We found that metabolites secreted by Erwinia/Pantoea and B. cepacia isolates had an inhibitory growth effect on some endophytic fungi, suggesting that these metabolites play a role in bacterial-fungal interactions inside the host plant. Apparently, these bacteria could have an important role in plant development; in the future they may be useful for biological control of diseases and plant growth promotion, as well as for the production of new metabolites and enzymes.

Key words: Endophytic bacteria; Plant-bacteria interaction; Erwinia; Pantoea

\section{INTRODUCTION}

Endophytic microorganisms have been defined as those that reside at some phase of their life cycle within living plant tissues (Carroll, 1986; Petrini, 1991). Endophytes have been found in all plants that have been examined (Saikkonen et al., 1998). These microorganisms include both commensal species, which have no direct effect on the host plant, and mutualistic symbionts, which could be used in the biological control of pathogens or plant growth promotion. The intimate relationship between endophytic bacteria and their host involves co-evolutionary processes, and may influence the physiological mechanisms of plants (Misaghi and Donndelinger, 1990). The role of endophytic communities in endophyte-plant interactions has been intensively discussed (Hallmann et al., 1997; Sturz et al., 2000). According to these cited authors, endophytic bacteria colonize an ecological niche similar to that of phytopathogens, especially vascular wilt pathogens. This could favor endophytes as candidates for biocontrol agents (Hallmann et al., 1997). Intensive work on biocontrol agents has shown that endophytic microorganisms isolated from surface-disinfected plant tissues exhibit potential as biocontrol agents against microbial pathogens (Pleban et al., 1995; Quecine et al., 2008; Ramesh et al., 2009), insects (Azevedo et al., 2000), and nematodes (Sikora et al., 2008). It has also been shown that in some cases endophytes can accelerate seed emergence and promote plant establishment under adverse conditions (Chanway, 1997) as well as increase plant growth and hasten plant development (Ting et al., 2008). On the other hand, the effects of endophytes may also be deleterious, possibly contributing to disease status (Araújo et al., 2002; Lacava et al., 2004), or some endophytes may interact with other endophytic populations (Araújo et al., 2001). Causes of these contrasting outcomes are mostly unclear, but they are very likely affected by the complex dynamics of interactions among endophytes, which are in turn affected by environmental conditions, plant species, and soil type.

In recent years, interest in endophytic microorganisms has increased, as they play a key role in agricultural environments and are promising because of their potential use in sustainable agriculture. The study of the genetic structure of endophytic microbial populations is important for understanding not only their ecological role in nature, but also for identifying the source of genetically engineered microorganisms released into the en- 
vironment (Amarger, 2002). An analysis of genotypic and phenotypic characteristics of endophytes may help to clarify the mechanism related to endophyte-plant interaction. This comprehension may represent the basis for the utilization of endophytic populations as inoculants, due to their ability to colonize the host plant and to compete with plant pathogens. As a consequence, the development of more adapted microorganisms may be favored, thus resulting in genotype selection. The understanding of the mutual influence between host plant and genetic diversity patterns of local microbial populations seems to be a requirement for evaluating the impact of a microbial inoculum, which could affect a preexisting balance among indigenous populations. Thus, analysis of the genetic structure of microbial populations has practical importance; the results can be used to assess the fate of released strains and their impact on resident microbial communities.

For eucalyptus, the natural incidence of bacterial endophytes has not been investigated. Therefore, the aims of this study were to analyze the diversity of the culturable endophytic bacterial community of stems from six Eucalyptus species grown under field condition and to study the interaction between endophytic bacteria and some endophytic fungi from Eucalyptus spp, which would help determine if the population of endophytic bacteria was associated with a plant genotype or may be affected by the geographic origin of the plant.

\section{MATERIAL AND METHODS}

\section{Plant material}

Endophytic bacteria and fungi were isolated from six Eucalyptus species (Eucalyptus citriodora, E. grandis, E. urophylla, E. camaldulensis, E. torelliana, E. pellita, and hybrid of E. grandis and E. urophylla), cultivated in Piracicaba, site P (IPEF, Instituto de Pesquisa e Estudos Florestais, SP, Brazil - 22 ${ }^{\circ} 41^{\prime} 4483^{\prime \prime} \mathrm{S} 47^{\circ} 38^{\prime} 3486^{\prime \prime} \mathrm{W}$ ) and Itapetininga, site I

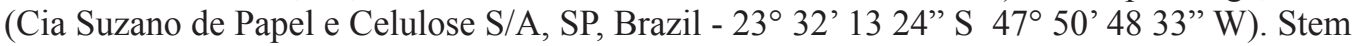
samples were randomly collected from 3 -year-old trees and immediately stored at $4^{\circ} \mathrm{C}$. All samples were processed within $24 \mathrm{~h}$ after being collected.

\section{Surface disinfection of stems}

The plant tissues were washed in running tap water and graded by size and surface appearance. Any visibly damaged material was excluded. Plant tissues were rinsed with $70 \%$ ethanol, surface-disinfected with sodium hypochlorite solution (3\% available $\left.\mathrm{Cl}^{-}\right)$for $3 \mathrm{~min}$, and rinsed once in $70 \%$ ethanol and twice in sterile distilled water. The efficiency of the disinfection process was checked by pressing the disinfected plant material onto both tryptic soy agar and potato dextrose agar (PDA). Aliquots of the water from the final rinsing solutions were also plated on the same media.

\section{Bacterial isolation}

Endophytic bacteria were isolated twice from all eucalyptus tree samples, and each stem was then cut into 15 fragments (4-6 mm), which were placed on tryptic soy agar contain- 
ing $50 \mu \mathrm{g} / \mathrm{mL}$ magnate $500 \mathrm{EC}$ (Imazalil) and $2 \mathrm{mg} / \mathrm{mL}$ polyvinylpyrrolidone. After 15-20 days of incubation at $28^{\circ} \mathrm{C}$, the number of pieces showing bacterial growth was counted. The endophyte incidence was calculated as the percentage of pieces showing bacterial growth. Bacterial colonies were picked randomly from the stem pieces, checked for purity, and further characterized by amplified rDNA restriction analysis (ARDRA).

\section{Fungal strains}

The E. grandis endophytic fungi Rhodotorula mucilaginosa (Rho), Botryosphaeria ribis (Bot), Schizophyllum commune (Sch), Pestalotiopsis microspora (Pes), Diaporthe helianthi (Dia), Cladosporium sp (Cla), Phaeoacremonium chlamydosporum (Pha), and Coniophora marmorata (Con) were obtained from the culture collection of the Laboratório de Genética de Microrganismos, Department of Genetics, Escola Superior de Agricultura "Luiz de Queiroz", University of São Paulo, Brazil.

\section{ARDRA-polymerase chain reaction}

Bacterial DNA was extracted according to the method given by Araújo et al. (2002), where amplification of $16 \mathrm{~S}$ rDNA was performed in a $50-\mu \mathrm{L}$ final volume containing $1 \mu \mathrm{L}$ (0.5-10.0 ng) total DNA, $0.2 \mu \mathrm{M}$ P027F primer (5'-GAGAGTTTGATCCTGGCTCAG-3'), $0.2 \mu \mathrm{M}$ 1378R primer (5'-CGGTGTGTACAAGGCCCGGGAACG-3'), $200 \mu \mathrm{M}$ of each $\mathrm{dNTP}, 3.75 \mathrm{mM} \mathrm{MgCl}_{2}$ and $0.05 \mathrm{U}$ Taq DNA polymerase (Invitrogen) in $20 \mathrm{mM}$ Tris- $\mathrm{HCl}$, $\mathrm{pH} 8.4$, containing $50 \mathrm{mM} \mathrm{KCl}$. A negative control [polymerase chain reaction (PCR) mixture without DNA] was included in all PCR experiments. The reaction conditions were as follows: $94^{\circ} \mathrm{C}$ for 4 min followed by 25 cycles of denaturation at $94^{\circ} \mathrm{C}$ for $30 \mathrm{~s}$, annealing at $63^{\circ} \mathrm{C}$ for $1 \mathrm{~min}$ and primer extension at $72^{\circ} \mathrm{C}$ for $1 \mathrm{~min}$, followed by a final extension at $72^{\circ} \mathrm{C}$ for $7 \mathrm{~min}$. The reaction products were separated by running $5 \mu \mathrm{L}$ of the PCR mixture on a $1.2 \%(\mathrm{w} / \mathrm{v})$ agarose gel and staining the bands with ethidium bromide (Sambrook et al., 1989). For ARDRA, $1 \mu \mathrm{g}$ amplified 16S rDNA fragment (1350 bp) was digested with AluI (AGCT), MobI (GATC) or HaeIII (GGCC) restriction enzyme (Invitrogen) according to manufacturer recommendations, and the products were run on a $2.5 \%(\mathrm{w} / \mathrm{v})$ agarose gel, stained with ethidium bromide and photographed under UV light.

\section{Sequencing of 16S rDNA}

For identification, the PCR product was purified using a GFX PCR DNA and gel band purification kit (Amersham Biosciences) and sequenced using the 1378R primer. Analyses of sequences were performed with the basic local alignment search tool BLASTn program run against the BLAST database (National Center for Biotechnology Information website [http:// www.ncbi.nlm.nih.gov]) and the ARB package software (Department of Microbiology, Technical University of Munich, Munich, Germany [http://www.arb-home.de]).

\section{RAPD analysis}

For each strain, random amplified polymorphic DNA (RAPD) analysis was carried 
out in a final volume of $25 \mu \mathrm{L}$, containing $5 \mathrm{ng}$ DNA template, $0.4 \mathrm{mM}$ primer, $200 \mu \mathrm{M}$ of each dCTP, dGTP, dATP, and dTTP (Invitrogen), $5 \mathrm{mM} \mathrm{MgCl}_{2}$ and $1.5 \mathrm{U}$ Taq DNA polymerase (Invitrogen) in $20 \mathrm{mM}$ Tris- $\mathrm{HCl}, \mathrm{pH} 8.4$, containing $50 \mathrm{mM} \mathrm{KCl}$. The amplification profile was as follows: 4 min initial denaturation at $92^{\circ} \mathrm{C}, 40$ cycles of $1 \mathrm{~min}$ at $92^{\circ} \mathrm{C}, 2$ min at $37^{\circ} \mathrm{C}$ and $3 \mathrm{~min}$ at $72^{\circ} \mathrm{C}$, followed by a final extension at $72^{\circ} \mathrm{C}$ for $3 \mathrm{~min}$. The PCR products were analyzed on $1.4 \%$ agarose gels stained with ethidium bromide. Negative control contained water instead of DNA.

Primers used were OPP-12 (5'-AAGGGCGAGT-3'), OPP-17 (5'-TGACCCGCCT-3'), OPP-19 (5'-GGGAAGGACA-3'), OPC-02 (5'- GTGAGGCGTC-3'), OPC-08 (5'-TGGACCGGTG-3'), OPC11 (5'-AAAGCTGCGG-3'), OPC-15 (5'-GACGGATCAG-3'), OPC-18 (5'-TGAGTGGGTG-3'), OPC20 (5'-ACTTCGCCAC-3'), OPP-12 (5'-AAGGGCGAGT-3'), OPP-17 (5'-TGACCCGCCT-3'), OPP19 (5'-GGGAAGGACA-3'), OPC-02 (5'-GTGAGGCGTC-3'), and OPC-08 (5'- TGGACCGGTG-3') supplied by Operon Technologies (Alameda, CA, USA).

\section{Data analysis}

The difference in total isolation frequency between Eucalyptus spp was tested by the Tukey test at 5\% significance. A dendrogram was constructed based on the simple matching coefficient $\left(\mathrm{S}_{\mathrm{sm}}\right)$ using band positions and UPGMA (unweighted pair group method with arithmetic mean) cluster analysis. A consensus tree was obtained using the Winboot software (Yap and Nelson, 1996) with 1000 bootstrap replicates.

\section{Interaction between endophytic bacteria and fungi}

Twenty endophytic bacterial isolates were collected randomly and tested for their antagonism against endophytic E. grandis fungi. This interaction was studied by co-culturing both microorganisms on PDA at $28^{\circ} \mathrm{C}$ for 5-10 days. Antagonistic effects of the endophytic bacteria toward fungi were evaluated by measuring the mycelial inhibition halo. To test for antagonism against yeasts, the PDA plate was inoculated with the endophytic bacterium and incubated at $28^{\circ} \mathrm{C}$ for $24 \mathrm{~h}$; the plate was then treated with chloroform for $2 \mathrm{~h}$ and incubated for $4 \mathrm{~h}$ to allow evaporation of the chloroform, and $50 \mu \mathrm{L}$ of a yeast suspension $\left(10^{4} \mathrm{CFU} / \mathrm{mL}\right)$ was spread over the plate surface. Inhibition was determined by measuring the zone of yeast growth inhibition after $24 \mathrm{~h}$ of incubation at $28^{\circ} \mathrm{C}$.

\section{RESULTS}

\section{Isolation of endophytic bacteria}

The diversity of endophytic bacteria of Eucalyptus plants was assessed in samples of stems collected from the two different growing areas of the State of São Paulo. Endophytic bacteria were consistently isolated from all plants evaluated, and this community was composed of Acinetobacter sp, Agrobacterium sp, Bacillus sp, Brevibacillus sp, Burkholderia sp, Curtobacterium sp, Erwinia sp, Lactococcus sp, Pantoea sp, and Pseudomonas sp. No bacteria were observed on control plates. The total isolation frequency was significantly different $(\mathrm{P}<0.05)$ between plant species (Figure 1A and B). 


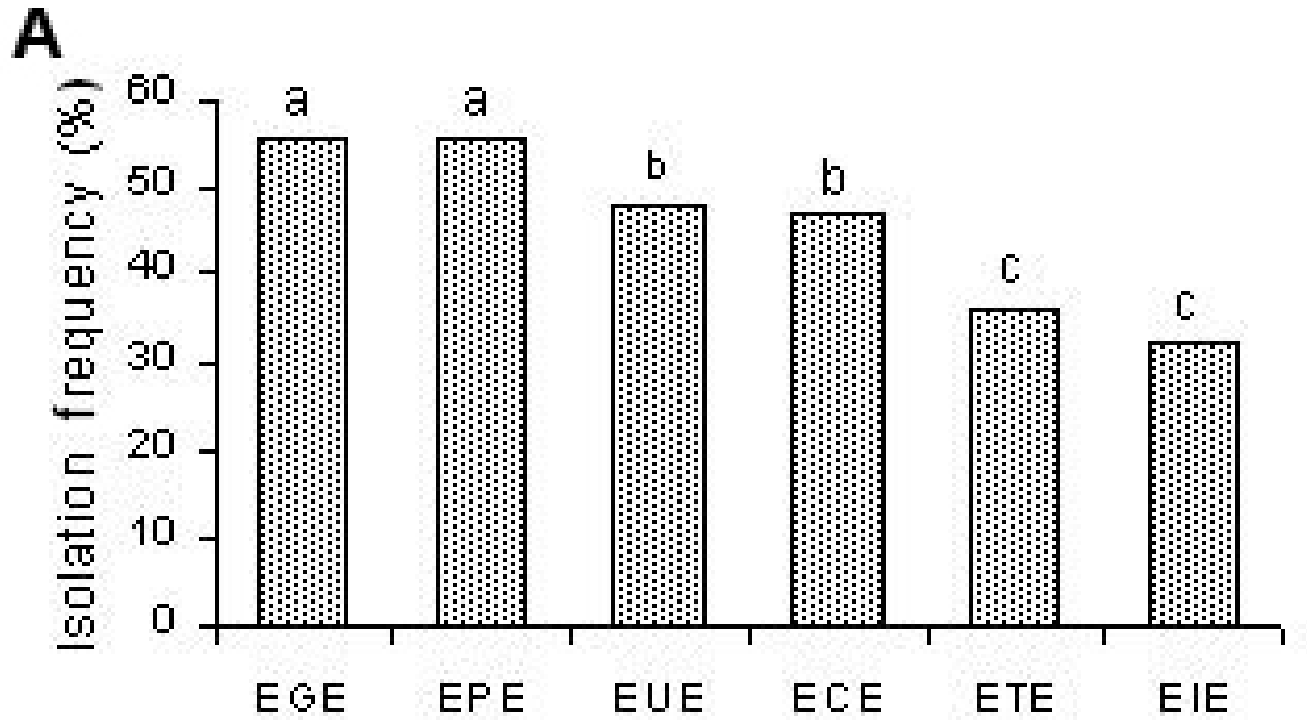

B

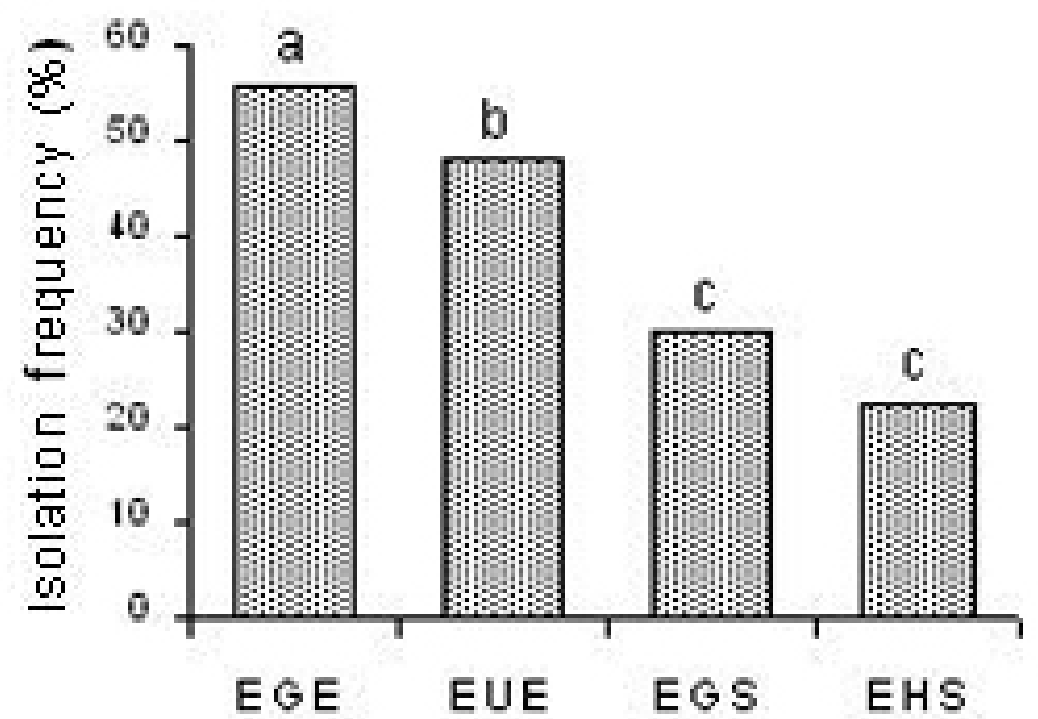

Figure 1. Incidence of endophytic bacteria in fragments of stems from Eucalyptus. A. From site $\mathrm{P}(\mathrm{EGE}=E$. grandis $; \mathrm{EPE}=E$. pellita $; \mathrm{EUE}=E$. urophylla $; \mathrm{ECE}=$ E. camaldulensis $; \mathrm{ETE}=$ E. torelliana $; \mathrm{EIE}=$ E. citriododra $)$. B. Site $\mathrm{I}[\mathrm{EGS}=$ E. grandis; $\mathrm{EHS}=$ hybrid $($ E. grandis $\mathrm{x}$ E. urophylla $)]$. 


\section{Amplification, restriction of 16S rRNA gene (ARDRA) and phylogenetic analysis}

A total of 76 endophytic bacteria isolated from stems of six Eucalyptus species were randomly picked, and this sample population was characterized by the ARDRA technique with $\mathrm{HaeIII}, A l u \mathrm{I}$ and $\mathrm{MboI}$ restriction enzymes. Each enzyme generated up to three fragments per isolate, resulting in eight haplotypes after combined analysis (Table 1). At least $20 \%$ of the isolates within each haplotype were identified by $16 \mathrm{~S}$ rDNA sequencing (Table 1), showing no relation between haplotypes and isolation site or host plant.

\begin{tabular}{|c|c|c|c|}
\hline Group & Isolates grouped by ARDRA profiles & Isolates identified by sequencing & Identification \\
\hline I & $\begin{array}{l}\text { EIE2, EPE8, EGS1, EGS4, EHS1, EGS3, EGE8, EHS2, } \\
\text { EHS3, EGS2, EUE7, ECE7, ECE6, ETE3, EIE3, EGE4, } \\
\text { EGE6, EIE6, EGE3, EPE6, EUE1, ETE1, ETE5, ETE8, } \\
\text { EUE6, ETE2, ETE7, ECE5, ECE4, ECE9, EPE2, EUE2, } \\
\text { EUE3, EUE5 }\end{array}$ & $\begin{array}{l}\text { EIE3, EGE6, EUE2, EUE5, ECE5, } \\
\text { ECE7, EPE2, EPE8, EGS1, EIE6, } \\
\text { EGE8, EUE3, EUE6, ECE6, ETE7, } \\
\text { EPE6, EGS4, EGS3, ETE8 }\end{array}$ & Erwinia/Pantoea \\
\hline II & $\begin{array}{l}\text { EIE1, EGE2, ECE8, ECE2, EUE4, EGE1, EPE1, EGS11, } \\
\text { EGS9, EGS7, EGS10, EGS8, EGS5, EGS6, ETE4, EPE4 }\end{array}$ & EIE1, EGE1, EGE2, EUE4 & Agrobacterium sp \\
\hline III & EIE8, EGE5, EPE7, EHS6, EHS4, EGS12, EHS10 & EIE8, EGE5, EHS4 & Curtobacterium $\mathrm{sp}$ \\
\hline IV & EIE9, EGS16, EGS17, ECE9, EIE10, EHS18 & EIE9, EGS16, EGS17 & Bacillus sp \\
\hline $\mathrm{V}$ & EIE5, EIE7, EGE7, EPE5, EPE3, EHS5 & EIE5, EPE5, EGE7 & Pseudomonas sp \\
\hline VI & EUE8, ECE3, EIE1 & EUE8, ECE3 & Acinetobacter $\mathrm{sp}$ \\
\hline $\begin{array}{l}\mathrm{VII} \\
\end{array}$ & EGS14, EGS15 & EGS14, EGS15 & Burkholderia sp \\
\hline VIII & ECE1, ETE6 & ECE1 & Lactococcus sp \\
\hline
\end{tabular}

Partial sequences of $16 \mathrm{~S}$ rDNA were aligned, and the relationships between endophytic isolates from different host Eucalyptus species were evaluated by a neighborjoining algorithm. Group I was identified as Erwinia/Pantoea (Figure 2A), group II as Agrobacterium sp (Figure 2B), group III as Curtobacterium sp (Figure 2C), group IV as Brevibacillus sp (Figure 2D), group V as Pseudomonas sp (Figure 2E), group VI as Acinetobacter sp (Figure 2F), group VII as Burkholderia cepacia (Figure 2G), and group VIII as Lactococcus lactis (Figure 2H). This analysis showed that the Enterobacteriaceae group, composed of genera X, Y and W, has divergent isolates that grouped together. No relation was observed between groups and host plant or isolation site. Also, this analysis allowed the identification of some isolates: in the Enterobacteriaceae group, the isolate ECE5 is related to Enterobacter pyrinus, and EIE6, EPE6 to Pantoea stewartii, while the isolates ETE3 and EUE3 may be identified as Erwinia (syn: Pectobacterium) carotovora. In the Pseudomonadaceae group, P. fulva (isolates EIE5 and EGE7) was observed (Figure 2E), as well as Burkholderia cepacia (isolate EGS15), Acinetobacter haemolyticus (isolates EUE8 and ECE3) and Lactococcus garviae (isolate ECE1). 


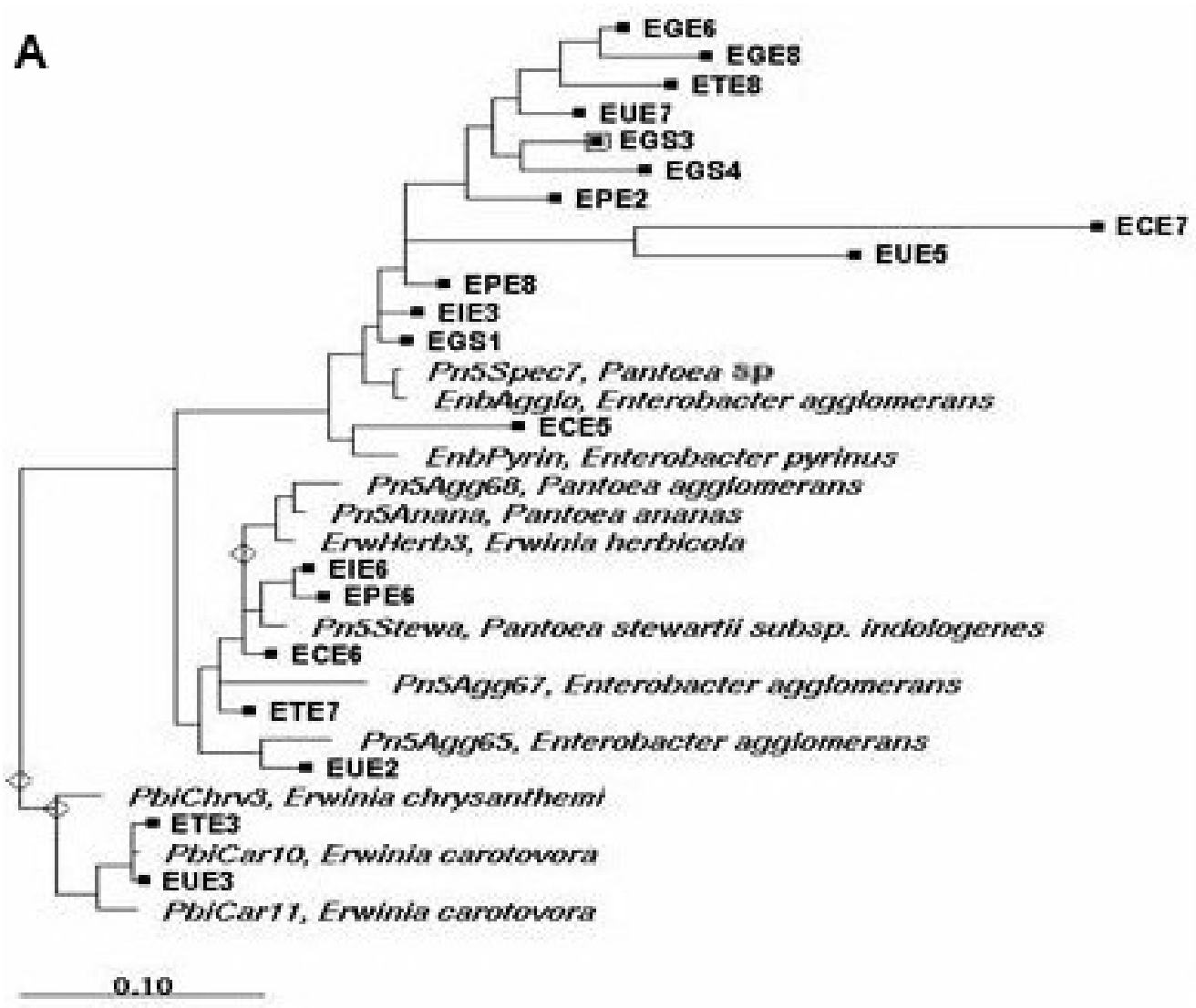

B

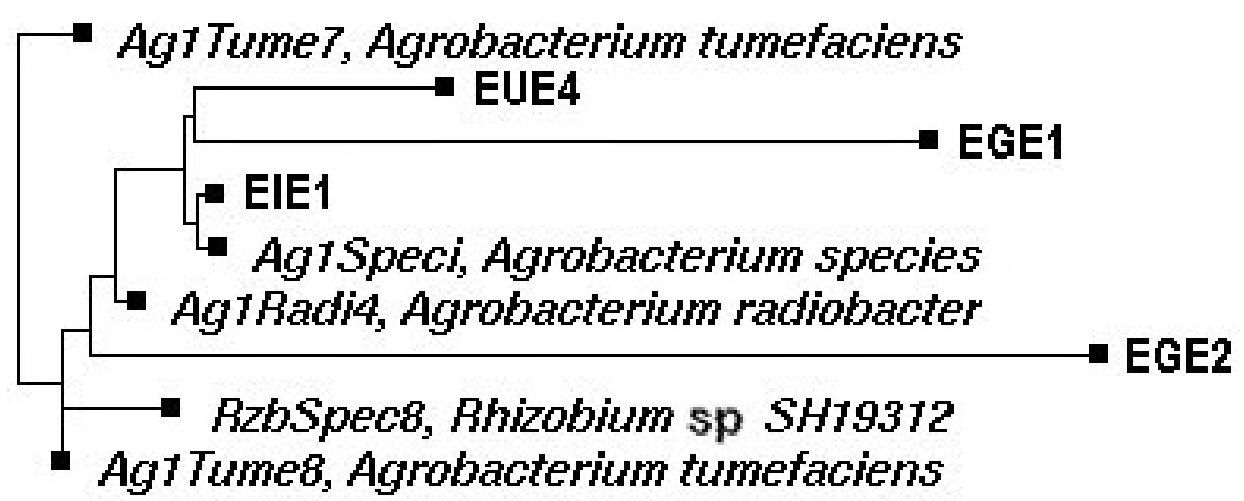

0.10 


\section{C}

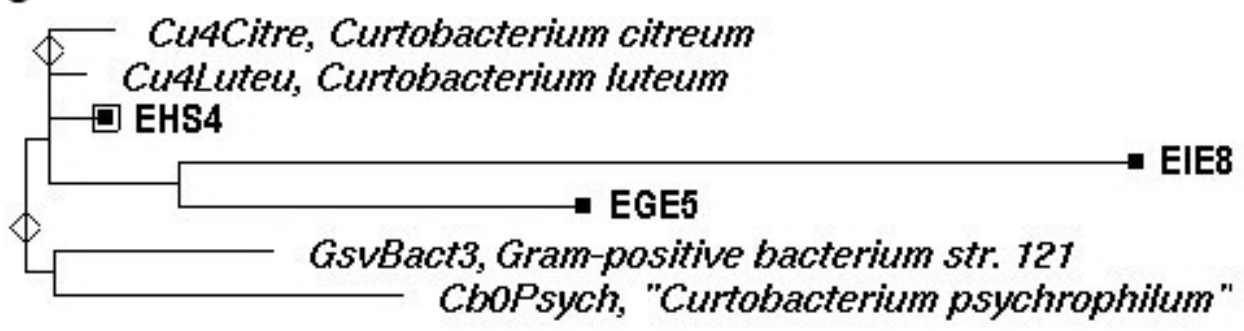

0.10

D BvcBrevi, Brevibacillus brevis

BvcAgri, Brevibacillus agri - EGS17

$\square$ EIE9

- EGS16

BvcLater, "Paenibacillus laterosporus"

BvcBorst, Brevibacillus borstelensis

0.10

E

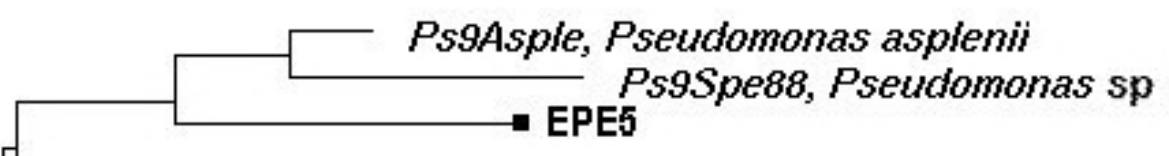

Ps9Put25, Pseudomonas putida

Ps3Spe86, Pseudomonas sp

$\square$ EIE5

- EGE7

PsgFulva, Pseudomonas fulva

0.10 
$\mathbf{F}$

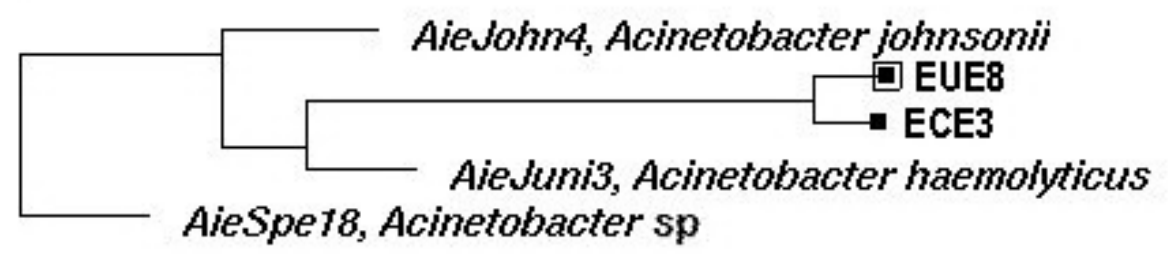

0.10

G

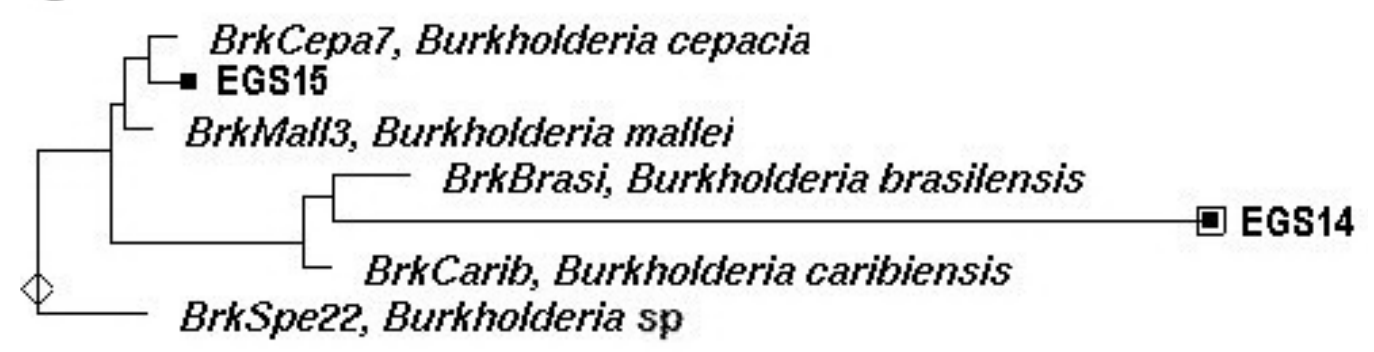

0.10

H

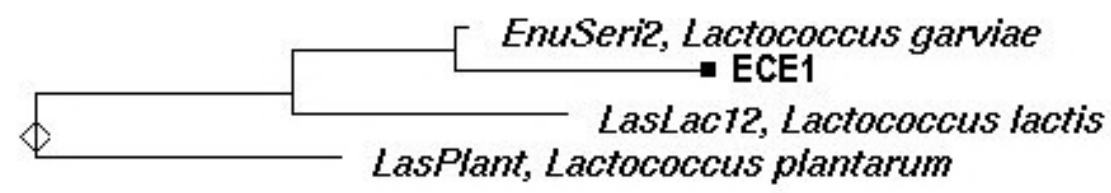

0.10

Figure 2. Phenogram based on the 16S rRNA gene sequences showing the phylogenetic relationships of endophytic isolates with the related established species. A. Erwinia/Pantoea. B. Agrobacterium sp. C. Curtobacterium sp. D. Bacillus sp. E. Pseudomonas sp. F. Acinetobacter sp. G. Burkholderia sp. H. Lactococcus sp (The scale bar represents a $10 \%$ estimated difference in nucleotide sequence). 


\section{Diversity analysis by RAPD markers}

Total DNA of endophytic bacteria belonging to the two most frequent groups $E r$ winia/Pantoea (group I) and Agrobacterium (group II) was amplified by the RAPD technique, with the reproducibility of the results being verified in independent experiments. Amplification patterns obtained from 16 Agrobacterium isolates exhibited a higher level of polymorphism than did those obtained from 34 Erwinia/Pantoea isolates. The relationships between the different Agrobacterium isolates as well as those between the Erwinia/ Pantoea isolates can be seen in the dendrograms based on the simple matching coefficient (Figure 3). These data show that there was no correlation between the groups obtained by RAPD markers and the host plants from which the endophytic bacteria were isolated. However, RAPD markers grouped Agrobacterium and Erwinia/Pantoea isolates according to isolation site. Isolates from the Suzano site, for both group, remained separate from the others, showing correlation with geographic origin of plants.

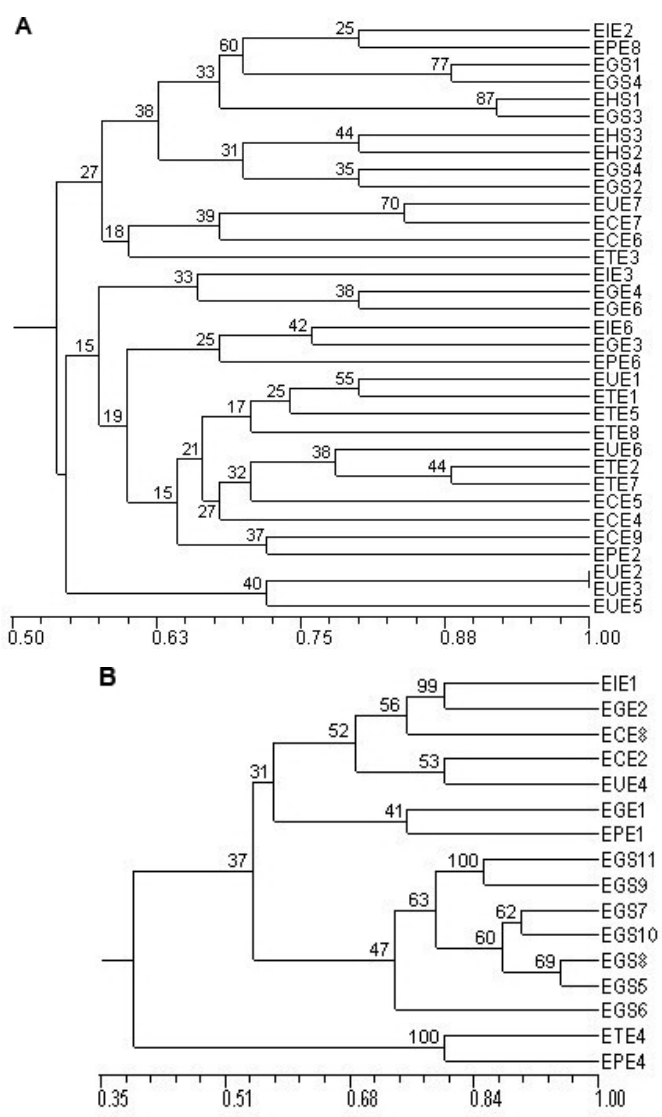

Figure 3. UPGMA dendrogram, based on Jaccard's coefficient, indicating the genetic relationships among isolates of Erwinia/Pantoea (A) and Agrobacterium (B). 


\section{In vitro interaction between endophytic fungi and bacteria}

The growth of 12 endophytic fungi in culture medium was inhibited by endophytic bacteria. Three isolates belonging to Erwinia/Pantoea were able to inhibit Botryosphaeria ribis (strains Bot1 and Bot2), Schizophyllum commune (strains Sch1 ad Sch2), Pestalotiopsis microspora (strains Pes1 and Pes2), and Diaporthe helianthi (strain Dia), whereas the isolate Spll2 (Burkholderia cepacia) inhibited all endophytic fungi tested except Phaeoacremonium chlamydosporum and Coniophora marmorata. In fact, these two fungi were not inhibited by any endophytic bacteria (Table 2).

\begin{tabular}{|c|c|c|c|c|c|c|c|c|c|c|c|c|c|}
\hline \multirow[t]{2}{*}{ Group } & \multirow[t]{2}{*}{ Strain } & \multicolumn{12}{|c|}{ Endophytic fungi } \\
\hline & & Rhol & Rho2 & Bot1 & Bot2 & Sch1 & Sch2 & Pes1 & Pes2 & Dia & $\mathrm{Cla}$ & Pha & Con \\
\hline $\bar{I}$ & EUE6 & - & - & - & - & - & - & - & - & - & - & - & - \\
\hline I & EPE8 & - & - & + & - & ++ & + & - & + & + & - & - & - \\
\hline I & EGS4 & - & - & - & - & - & - & - & - & - & - & - & - \\
\hline I & EUE3 & - & - & + & + & + & + & + & ++ & + & - & - & - \\
\hline I & ECE4 & - & - & - & - & - & - & - & - & - & - & - & - \\
\hline I & EUE7 & - & - & + & + & ++ & ++ & + & ++ & ++ & - & - & - \\
\hline I & EGE6 & - & - & - & - & - & - & - & - & - & - & - & - \\
\hline I & EGS3 & - & - & + & + & - & + & - & - & - & - & - & - \\
\hline I & EGS2 & - & - & - & - & - & + & - & + & - & - & - & - \\
\hline I & EPE6 & - & - & + & + & ++ & ++ & + & ++ & ++ & - & - & - \\
\hline II & EIE1 & - & - & - & - & - & - & - & - & - & - & - & - \\
\hline II & ECE8 & - & - & - & - & - & - & - & - & - & - & - & - \\
\hline II & EPE1 & - & - & - & - & - & - & - & - & - & - & - & - \\
\hline II & EGS7 & - & - & - & - & - & - & - & - & - & - & - & - \\
\hline II & EGS5 & - & - & - & - & - & - & - & - & - & - & - & - \\
\hline III & EIE8 & - & - & - & - & - & - & - & - & - & - & - & - \\
\hline III & EHS4 & - & - & - & - & - & - & - & - & - & - & - & - \\
\hline III & EGS12 & - & - & - & - & - & - & - & - & - & - & - & - \\
\hline $\mathrm{V}$ & EIE5 & - & - & - & - & - & - & - & - & - & - & - & - \\
\hline VII & EGS15 & ++ & ++ & +++ & ++ & +++ & ++ & ++ & +++ & ++ & + & - & - \\
\hline
\end{tabular}

Rho = Rhodotorula mucilaginosa $;$ Bot $=$ Botryosphaeria ribis $; \mathrm{Sch}=$ Schizophyllum commune $;$ Pes $=$ Pestalotiopsis microspora $; \mathrm{Dia}=$ Diaporthe helianthi $\mathrm{Cla}=$ Cladosporium $\mathrm{sp} ; \mathrm{Pha}=$ Phaeoacremonium chlamydosporum; Con $=$ Coniophora marmorata.- , No inhibition; + , weak inhibition $(<5 \mathrm{~mm}) ;++$, moderate inhibition $(<10 \mathrm{~mm}) ;+++$, strong inhibition $(>10 \mathrm{~mm})$.

\section{DISCUSSION}

Plant-associated bacteria may significantly influence plant growth positively or negatively (Hallmann et al., 1997), and alternatively, plant conditions affect associated endophytic bacterial communities (Araújo et al., 2002; Lacava et al., 2004; Kuklinsky-Sobral et al., 2004). In the present study, differences in frequency of endophytic bacteria were observed among Eucalyptus species, suggesting that the host species has an influence on the population of endophytic bacteria, as observed in cotton and peas, where plant colonization by endophytic bacteria is affected by plant genotype (Elvira-Recuenco and Van Vuurde, 2000; Adams and Kloepper, 2002; Raja et al., 2008).

In our RAPD analysis, endophytic bacteria formed sub-populations, thus indicating 
that they were specifically suited to colonizing their respective niches and had specific phenotypes. For example, Agrobacterium isolates with the same ARDRA profile formed at least two different groups (Figure 3B), the first isolated from Suzano and the second from IPEF, which may indicate adaptation to an endophytic environment and geographic area. A similar result was observed for population. In other words, isolates from the Suzano site may be present only in this area and have physiological and genetic characteristics that result in a close association with plant tissues inside host plants. These results confirmed that the genomic backgrounds of endophytic bacteria were related to the geographic origin. This phenomenon is universal, and had been found in endophytes ( $\mathrm{Li}$ et al., 2008). Management practice applied in the fields may induce stress on the microbial communities and, as a consequence, reduce the genomovar diversity of Burkholderia cepacia (Fiore et al., 2001).

Analysis based on the sequence of the 16S rRNA gene represents a highly accurate and versatile method for bacterial classification and identification, where the features of this molecular target, the universal distribution among bacteria and the presence of species-specific variable regions make it a useful tool not only for detection and identification of environmental isolates but also for phylogenetic analysis (Kwon et al., 1997; Sun et al., 2008). The result of our screening for culturable Eucalyptus endophytic bacteria clearly indicated that a wide range of microorganisms, from diverse phylogenetic affiliations, could inhabit Eucalyptus plant tissues. The most representative groups were assigned to the Enterobateriaceae (Pantoea/Erwinia) and Agrobacterium genera; therefore, these microorganisms may be considered the dominant groups in Eucalyptus. This stable biodiversity is considered to be the most important condition in the establishment of any ecosystem. Recent evidence obtained by cultivation-based and molecular analysis suggests that the Enterobacteriaceae group are the most important endophytes in peas (Elvira-Recuenco and Van Vuurde, 2000), Eucalyptus (Coutinho et al., 2002) and citrus (Araújo et al., 2001) and can be isolated from other plant species (Wang et al., 2006; Zhang et al., 2008, Li et al., 2008; Torres et al., 2008). Enterobacteriaceae have been isolated from many different plants species, suggesting that these bacteria have developed an evolutionary niche within plants (Lodewyckx et al., 2002; Waleron et al., 2002). Previously, Kuklinsky-Sobral et al. (2004) found that these endophytic bacteria of soybean had the potential for promoting plant growth by the production of IAA, solubilization of mineral phosphate, and nitrogen fixation. Previous study has shown that Eucalyptus plants seem to be intensively colonized by Enterobacteriaceae, which may result, in some conditions, in the development of plant disease (Coutinho et al., 2002). The cited authors observed that although many Enterobacteriaceae species were observed, Pantoea ananatis was described as the causal agent of dieback of Eucalyptus species. The continuum of antagonistic-mutualistic interactions for any two interacting species depends on phylogenetic and life history constraints, geography, interaction with other species in the community, and abiotic factors (Saikkonen et al., 1998). However, in the present study, no dieback symptoms were observed, suggesting that this pathogenic bacterium is not present in the Eucalyptus plants evaluated.

Endophytic bacteria obtained in this study exhibit antagonism against endophytic fungi (Botryosphaeria ribis, Schizophyllum commune, Pestalotiopsis microspora, Diaporthe helianthi, Cladosporium and Rhodotorula mucilaginosa) obtained in a previous study. These bacteria belong to Erwinia/Pantoea and Burkholderia cepacia, which suggests that some competition between these microorganisms may occur inside Eucalyptus plants. In rice, Bacillus, Pantoea and Burkholderia inhibit the growth of phytopathogenic fungi 
such as Magnaporthe grisea, Fusarium moniliforme and Rhizoctonia solani (Yang et al., 2008). Many of the Burkholderia isolates from sugarcane produced antifungal metabolites (Mendes et al., 2007), indicating that a complex interaction occurs inside the host plant. This antagonism displayed by endophytic bacteria against phytopathogenic fungi may be used to control several plant diseases (Cho et al., 2007). An understanding of the factors affecting the population of endophytic bacteria is necessary to achieve a consistent application of these bacteria. The presence of endophytic bacteria in Eucalyptus suggests that they can be utilized in future application, such as to enhance agricultural production, decrease susceptibility to disease and increase resistance to stress conditions.

In conclusion, intraspecific biodiversity enables environmental microorganisms to adapt to changing habitats, resulting in a particular biotype that responds best to the stress being favored. Moreover, the decrease in bacterial population is significantly influenced by location of the host plant, because it creates an environment in which another genotype will be the superior competitor. In an environment that affords ecological opportunity and where selection has favored the evolution of niche-specialist genotypes, the maintenance of coexisting genotypes is assured through the operation of densitydependent processes. Assuming a constant primary resource, the fitness of a niche-specialist genotype will be a function of the availably of the primary resource. Therefore, selection will operate in a negative frequency-dependent manner, favoring genotypes when they are rare (because resources will be most abundant) but not when they are common (because resources will be scare and competition intense).

\section{ACKNOWLEDGMENTS}

Research supported by a grant from Cia. Suzano de Papel e Celulose S.A. We thank FAPESP for the fellowships to R.E.L. Procópio (\#00/07053-2) and W.L. Araújo (\#00/10699-1).

\section{REFERENCES}

Adams PD and Kloepper JW (2002). Effect of host genotype on indigenous bacterial endophytes of cotton (Gossypium hirsutum L.) Plant Soil 240: 181-189.

Amarger N (2002). Genetically modified bacteria in agriculture. Biochimie 84: 1061-1072.

Araújo WL, Maccheroni W Jr, Aguilar-Vildoso CI, Barroso PA, et al. (2001). Variability and interactions between endophytic bacteria and fungi isolated from leaf tissues of citrus rootstocks. Can. J. Microbiol. 47: 229-236.

Araújo WL, Marcon J, Maccheroni W Jr, Van Elsas JD, et al. (2002). Diversity of endophytic bacterial populations and their interaction with Xylella fastidiosa in citrus plants. Appl. Environ. Microbiol. 68: 4906-4914.

Azevedo JL, Maccheroni W Jr, Pereira JO and Araújo WL (2000). Endophytic microorganisms: a review on insect control and recent advances on tropical plants. Electr. J. Biotechnol. 3: 40-65.

Carroll GC (1986). The Biology of Endophytism in Plants with Particular Reference to Woody Perennials. In: Microbiology of Phyllosphere (Fokkema NJ and van den Heuvel J, eds.). Cambridge University Press, London, 205-222.

Chanway CP (1997). Inoculation of tree roots with plant growth promoting soil bacteria: an emerging technology for reforestation. Forest Sci. 43: 99-112.

Cho KM, Hong SY, Lee SM, Kim YH, et al. (2007). Endophytic bacterial communities in ginseng and their antifungal activity against pathogens. Microb. Ecol. 54: 341-351.

Coutinho TA, Preisig O, Mergaert J, Cnockaert MC, et al. (2002). Bacterial blight and dieback of Eucalyptus species, hybrids, and clones in South Africa. Plant Dis. 86: 20-25.

Elvira-Recuenco M and Van Vuurde JW (2000). Natural incidence of endophytic bacteria in pea cultivars under field conditions. Can. J. Microbiol. 46: 1036-1041. 
Fiore A, Laevens S, Bevivino A, Dalmastri C, et al. (2001). Burkholderia cepacia complex: distribution of genomovars among isolates from the maize rhizosphere in Italy. Environ. Microbiol. 3: 137-143.

Hallmann J, Mahaffee WF, Kloepper JW and Quadthallmann A (1997). Bacterial endophytes in agricultural crops. Can. J. Microbiol. 43: 895-914.

Kuklinsky-Sobral J, Araújo WL, Mendes R, Geraldi IO, et al. (2004). Isolation and characterization of soybean-associated bacteria and their potential for plant growth promotion. Environ. Microbiol. 6: 1244-1251.

Kwon SW, Go SJ, Kang HW, Ryu JC, et al. (1997). Phylogenetic analysis of Erwinia species based on 16S rRNA gene sequences. Int. J. Syst. Bacteriol. 47: 1061-1067.

Lacava PT, Araújo WL, Marcon J, Maccheroni W Jr, et al. (2004). Interaction between endophytic bacteria from citrus plants and the phytopathogenic bacteria Xylella fastidiosa, causal agent of citrus-variegated chlorosis. Lett. Appl. Microbiol. 39: 55-59.

Li JH, Wang ET, Chen WF and Chen WX (2008). Genetic diversity and potential for promotion of plant growth detected in nodule endophytic bacteria of soybean grown in Heilongiiang province of China. Soil Biol. Biochem. 40: 238-246.

Lodewyckx C, Vangronsveld J, Porteous F, Moore ERB, et al. (2002). Endophytic bacteria and their potential applications. Crit. Rev. Plant Sci. 21: 583-606.

Mendes R, Pizzirani-Kleiner AA, Araújo WL and Raaijmakers JM (2007). Diversity of cultivated endophytic bacteria from sugarcane: genetic and biochemical characterization of Burkholderia cepacia complex isolates. Appl. Environ. Microbiol. 73: 7259-7267.

Misaghi IJ and Donndelinger CR (1990). Endophytic bacteria in symptom-free cotton plants. Phytopathology 80: 808-811.

Petrini O (1991). Fungal Endophyte of Tree Leaves. In: Microbial Ecology of Leaves (Andrews J and Hirano SS, eds.). Spring-Verlag, New York, 179-197.

Pleban S, Ingel F and Chet I (1995). Control of Rhizoctonia solani and Sclerotium rolfsii in the greenhouse using endophytic Bacillus spp. Eur. J. Plant Pathol. 101: 665-672.

Quecine MC, Araujo WL, Marcon J, Gai CS, et al. (2008). Chitinolytic activity of endophytic Streptomyces and potential for biocontrol. Lett. Appl. Microbiol. 47: 486-491.

Raja P, Balachandar D and Sundaram SP (2008). Genetic diversity and phylogeny of pink-pigmented facultative methylotrophic bacteria isolated from the phyllosphere of tropical crop plants. Biol. Fertil. Soils 45: 45-53.

Ramesh R, Joshi AA and Ghanekar MP (2009). Pseudomonads: major antagonistic endophytic bacteria to suppress bacterial wilt pathogen, Ralstonia solanacearum in the eggplant (Solanum melongena L.). World J. Microbiol. Biotechnol. 25: 47-55.

Saikkonen K, Faeth SH, Helander M and Sullivan TJ (1998). Fungal endophytes: a continuum of interactions with host plants. Ann. Rev. Ecol. Syst. 29: 319-343.

Sambrook J, Fritsch EFE and Maniatis T (1989). Molecular Cloning - A Laboratory Manual. Cold Spring Harbor Laboratory Press, New York.

Sikora RA, Pocasangre L, Felde A, Niere B, et al. (2008). Mutualistic endophytic fungi and in-planta suppressiveness to plant parasitic nematodes. Biol. Control 46: 15-23.

Sturz AV, Christie BR and Nowak J (2000). Bacterial endophytes: potential role in developing sustainable systems of crop production. Crit. Rev. Plant Sci. 19: 1-30.

Sun L, Qiu F, Zhang X, Dai X, et al. (2008). Endophytic bacterial diversity in rice (Oryza sativa L.) roots estimated by $16 \mathrm{~S}$ rDNA sequence analysis. Microb. Ecol. 55: 415-424.

Ting ASY, Meon S, Kadir J, Radu S, et al. (2008). Endophytic microorganisms as potential growth promoters of banana. BioControl 53: 541-553.

Torres AR, Araújo WL, Cursino L, Hungria M, et al. (2008). Diversity of endophytic enterobacteria associated with different host plants. J. Microbiol. 46: 373-379.

Waleron M, Waleron K, Podhajska AJ and Lojkowska E (2002). Genotyping of bacteria belonging to the former Erwinia genus by PCR-RFLP analysis of a recA gene fragment. Microbiology 148: 583-595.

Wang ET, Tan ZY, Guo XW, Rodriguez-Duran R, et al. (2006). Diverse endophytic bacteria isolated from a leguminous tree Conzattia multiflora grown in Mexico. Arch. Microbiol. 186: 251-259.

Yang JH, Liu HX, Zhu GM, Pan YL, et al. (2008). Diversity analysis of antagonists from rice-associated bacteria and their application in biocontrol of rice diseases. J. Appl. Microbiol. 104: 91-104.

Yap I and Nelson RJ (1996). Winboot: A Program for Performing Bootstrap Analysis of Binary Data to Determine the Confidence Limits of UPGMA-based Dendrograms. International Rice Research Institute, Manila.

Zhang GX, Peng GX, Wang ET, Yan H, et al. (2008). Diverse endophytic nitrogen-fixing bacteria isolated from wild rice Oryza rufipogon and description of Phytobacter diazotrophicus gen. nov. sp. nov. Arch. Microbiol. 189: 431-439. 